\title{
A repellent to reduce mouse damage to longleaf pine seed
}

\author{
Dale L. Nolte ${ }^{\mathrm{a}, *}$, James P. Barnett ${ }^{\mathrm{b}}$ \\ "USDA/APHIS/WS/National Wildiffe Research Center. 9730-B Lathrop Industrial Drive, Olympia, WA 98512, USA \\ 'USDA Forest Service, Southern Research Station, 2500 Shreveport Highway, Pineville, LA 71360 , U SA
}

\begin{abstract}
Direct seeding is a potential method for reforestation of pines on many southern sites. The success of direct seeding, however, depends, at least in part, in reducing seed predation by birds and rodents. We conducted a series of tests to assess the efficacy of' capsicum and thiram in reducing mouse damage to longleaf pine (Pinus palustris) seeds. House mice (Mus musculus) predation was reduced $(\mathrm{P}<0.05)$ by treating seeds with either capsicum or thiram or a mixture of the two ingredients. Deer mice (Peromyscus maniculatus) avoided seeds treated with a mixture of capsicum and thiram. We conclude that the capsicum and thiram mixture should be pursued as a potential repellent to protect longleaf pine seeds from animal predation when these seeds are used in direct seeding efforts to establish southern pine forests. Published by Elsevier Science Ltd.
\end{abstract}

Keywords: Deer mice; House mice; Mus musculus: Perom!̣seus maniculatus; Damage reduction: Pinus palustris; Repellents; Seeds

\section{Introduction}

Reforestation often requires extensive efforts across large areas. Planting seedlings eliminates some problems, but it is labor-intensive and requires additional costs. Direct seeding is an affordable alternative to planting on many sites needing reforestation of southern pines. Artificial seeding also is an appropriate supplement to natural regeneration where seedfall from parent trees is inadequate. Seeding techniques were thoroughly researched during the 1950s, 1960s (Derr and Mann, 1971), and the 1970s (Campbell, 1981 b, 1981c). These studies demonstrated that success depends, at least in part, on reducing seed predation by birds and rodents (Derr and Mann, 1971; Campbell, 1981b, 1981c).

Campbell (1981a) demonstrated that a formulation of endrin and thiram effectively repelled the more abundant species of seed-eating birds and mammals common to most southern pine sites. Endrin is a toxic insecticide that was registered as a rodent repellent in

\footnotetext{
* Corresponding author.
}

forestry, but because of limited demand it is no longer manufactured in the United States (Barnett et al., 1980). Therefore, the continued use of direct seeding in southern forestry may depend on finding a satisfactory substitute (Barnett, 1998).

Thiram (tetramethylthiuram disulfide), a fungicide currently marketed as Gustafson $42-S^{R 2}$, is relatively safe and easy to use (Barnett, 1998). Thiram emits a sulfurous odor (Nolte, 1998a) and when ingested can induces a conditioned food aversion (Campbell and Bullard, 1972). Sulfurous odors are generally avoided by herbivores and attract carnivores (Nolte et al., 1994b), which can induce a dual impact by repelling small herbivorous species (e.g., voles) while increasing predator pressure against those individuals that remain (Nolte, 1998b). Thiram is registered as a bird repellent (Clark, 1998), and has shown promise to repel some species. Avery and Decker (1991) demonstrated that red-winged blackbirds (Agelaius phoeniceus) reduce their consumption of rice seeds treated with $1.0 \%$ thiram in laboratory trials. Schafer et al. (1983) also demonstrated an avoidance of $1.0 \%$ thiram by passerines. Treating seeds with thiram $(0.5 \%)$, however, did not reduce house crow (Corvus splendens) damage to 
sprouting sunflowers (Dhindsa et al., 1991). Whether the difference in the extent of seed protection among these studies reflects bird species tested, thiram concentrations, treatment conditions, or a combination of these and other factors is unknown.

Barnett (1995) and Campbell (1981c) evaluated several aversive agents as potential replacements for endrin. Unfortunately, the original compounds they tested failed to meet their criteria for an effective repellent to protect seeds from predation. These criteria required that a compound be relatively benign to the seeds, and that it deter feeding by the target animals.

Barnett (1998) identified oleoresin of capsicum as a potential product that did not hinder germination yet repelled small mammals. Capsicum stimulates specialized trigeminal pain receptors (nociceptors) present in exposed mucous membranes of the eyes, mouth, nose and gut lining (Green et al., 1990), in mammals, producing the type of stimulation that humans describe as burning, itching, or tingling (Rozin et al., 1982). Capsicum is irritating to mammals at relatively low concentrations and therefore avoided. Curiously, there are profound taxonomic differences between avian and mammalian trigeminal chemoreception. Mammalian irritants are rarely aversive to birds, and vice versa (Mason et al., 1991). For example, some mammals avoid capsaicin concentrations as low as 1-10 parts per million, while birds tolerate capsaicin concentrations as high as 20,000 parts per million in drinking water (Mason et al., 1991). Thus, a repellent containing capsicum is likely to be avoided by small rodents; however, the addition of capsicum is unlikely to deter consumption by birds.

A repellent applied to reduce seed predation must not negatively impact seed germination. Barnett (1998) assessed the impact of capsicum, and capsicum combined with thiram, on the germination of longleaf pine (Pinus palustris) seeds, under standard laboratory conditions for 28 days (Association of Official Seed Analysts, 1980). Capsicum concentrations greater than 1.6 $\mathrm{ml}$ reduced seed germination. Prior trials also have suggested that reduced seed germination can be expected if seeds are treated with thiram (Campbell, 1981c), but field germination is generally higher in the field than indicated by laboratory trials (Barnett et al., 1980; Campbell, 1981 c).

Barnett (1998) also evaluated animal response to seeds treated with capsicum or a capsicum and thiram mixture. Seeds rapidly disappeared during this trial with $78 \%$ of the untreated seeds gone within the first 11 days. Treating seeds with capsicum reduced seed consumption, but not as significantly as that achieved with the mixture. Seed-coat fragments found in the plots during trial evaluations suggested that both birds and rodents were feeding on the longleaf pine seeds. Thus, the additional losses may have reflected increased bird predation on capsicum treated seeds when thiram was absent.

We conducted a series of tests to further assess the efficacy of capsicum and thiram to deter mouse damage to longleaf pine seeds. Both one-choice and two-choice tests were conducted to elucidate the characteristics of the response to the repellents (Mason et al., 1989). Two-choice tests were employed because they are a more sensitive measure whether an animal differentiates between stimuli, while one-choice tests more accurately assess whether a stimulus exerts strong effects (Nolte and Mason, 1998).

\section{Two-choice tests}

\subsection{Subjects}

Twelve experimentally naive adult ( $>60$ days of age) male deer mice (Peromyscus maniculatus) and 12 house mice (Mus musculus) served as subjects. Mice were obtained from breeding colonies maintained by the National Wildlife Research Center; procedures were identical for both species. Animals were individually caged in a nest box $(42 \times 28 \times 30 \mathrm{~cm})$ with a I-m length of clear tube $(5 \mathrm{~cm}$ diameter) protruding from its center. A cap at the end of the tube prevented mice from escaping, but also permitted a goal box to be easily attached. The bottom of the nest box was covered with wood shavings, and animals had free access to water throughout the experiment.

\subsection{Repellents}

Treatments were the same as used in the prior study by Barnett (1998). All treated seeds received a basic application of $3 \mathrm{ml}$ of latex, and $45 \mathrm{~g}$ of kaolin clay in $100 \mathrm{ml}$ of water per $454 \mathrm{~g}$ of seeds. The test repellents consisted of this basic application with $76 \mathrm{ml}$ of thiram (THI), $0.6 \mathrm{ml}$ of capsicum (CAP), or both $76 \mathrm{ml}$ of thiram and $0.6 \mathrm{ml}$ of capsicum $(\mathrm{T}+\mathrm{C})$. The strength of capsicum used in this study were 500,000 Scoville Units (SV); pure capsaicin is $165,000,000 \mathrm{SV}$. SV is the industry standard for measuring the heat of peppers (American Spice Trade Association, 1960; Hoffman and Lego, 1983). A SV reflects the concentration of capsaicin, the chemical which stimulates trigeminal receptors; $15 \mathrm{SV}$ is equivalent to $1 \mathrm{ppm}$ capsaicin. The concentration used in this experiment is roughly equivalent to the capsaicin concentration found in habernero peppers, the 'hottest' pepper known to exist (Chile Pepper Institute, 1994). Untreated longleaf pine seeds, not treated with the basic application, served as controls. 


\subsection{Procedures}

Two-choice tests were conducted to determine the relative efficacy of the repellents when offered to mice at the same time as untreated seeds, and to assess whether mice differentiated between repellent-treated seeds and untreated seeds.

Animals were adapted to an 18 -h food deprivation period prior to experimental procedures. Rodents were first subjected to an adaptation period for at least 4 days. At 0900 hours, a goal box with a divider at the rear was attached to the tube protruding from the nest box. Dimensions of the goal box were identical to the nest box. The divider extended $15 \mathrm{~cm}$ into the box separating food dishes placed on either side. Laboratory rodent chow (Purina) was available in both food trays for the next $6 \mathrm{~h}$. At 1500 hours the tube was disconnected from the goal box and any cached food was removed.

Test procedures were identical to those for the 4-day adaptation period except between 0900 and 1200 hours the mice were offered a choice between 20 untreated longleaf pine seeds and 20 longleaf pine seeds treated with one of three repellents (CAP, THI, C + T). Each two-choice test was conducted on two consecutive days. The order of tests was counterbalanced among animals. Seeds were removed at 1200 hours. Animals then were provided free access to the rodent chow until 1500 hours, at which time the mice were again excluded from the goal box without access to food. The process was repeated until each mouse had undergone each of the three, two-choice test.

\subsection{Statistical comparisons}

Mouse response to treatments was determined by counting the number of seeds damaged by mice. A seed was considered damaged if a mouse chewed through any part of the seed coat. Difference scores then were calculated for each treatment. The number of treated seeds damaged was subtracted from the number of untreated seeds damaged. Thus, the higher the difference score the greater the avoidance of treated seeds relative to untreated seeds. Negative difference scores reflect an exhibited preference for the repellent treated seeds. A three-factor repeated measures analysis of variance (ANOVA) was used to compare the suppression scores of the repellents for each species. The repeated measures was days (2 levels) and the independent factors were treatment (3 levels) and test order (6 levels). Tukey tests were used to isolate differences among means subsequent to the omnibus procedures.

A two-factor repeated measures ANOVA was used to determine whether mice differentiated between the treated and untreated seeds for each repellent. The

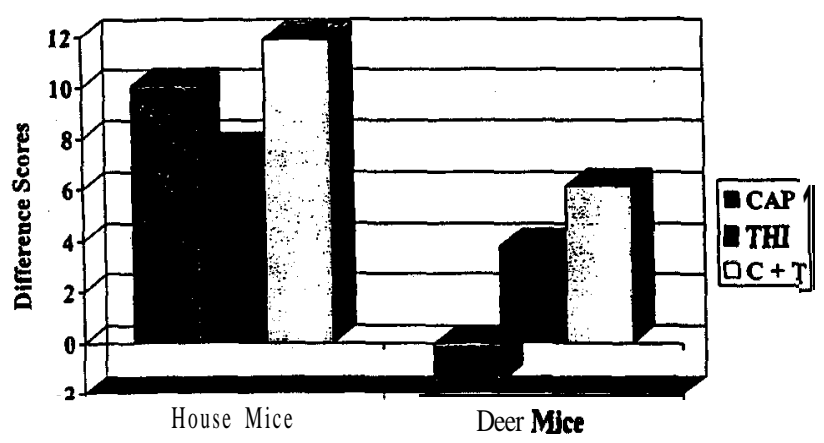

Fig. 1. Mean difference scores of house mice and deer mice when offered a choice between seeds treated with CAP, THI or $\mathrm{C}+\mathrm{T}$ and untreated seeds.

repeated measure was days ( 2 levels) and the other factor was treatment (2 levels).

\subsection{Results}

Difference scores of house mice were not affected by the order of test $(P=0.3138)$, the treatment $(\mathrm{P}=0.0697)$, or the day of test $(\mathrm{P}>0.35)$ (Fig. 1$)$. There was an order by treatment $(\boldsymbol{P}=0.0191)$ and an order by day interaction $(P=0.0223)$. There were no other significant interactions. House mice damaged fewer CAP $(P=0.0006)$, THI $(\mathrm{P}=0.0010 O)$, and $\mathrm{C}+$ T $(P=0.0002)$ treated seeds than they did untreated seeds in these two-choice tests (Fig. 2).

Deer mice responses varied among treatments $(P=$ 0.0144) (Fig. 1), but difference scores were not affected by the order of test $(P=0.0649)$, or day of test $(\mathrm{P}>0.35)$. There were no significant interactions. Fewer $\mathrm{C}+\mathrm{T}$ treated seeds were damaged than untreated seeds $(P=0.0116)$ when deer mice were offered a choice between these two treatments (Fig. 2). Deer mice did not differentiate between CAP treated and untreated seeds $(P>0.35)$ or between THI treated and untreated seeds $(P=0.1605)$ when offered these choices (Fig. 2).

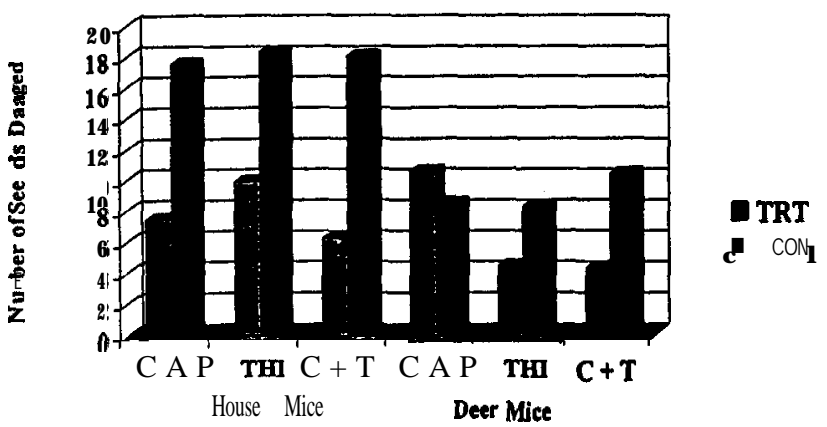

Fig. 2. Mean number of treated (CAP, THI, $\mathrm{C}+\mathrm{T}$ ) and untreated seeds damaged by house mice and deer mice when offered a choice between treated and untreated seeds. 


\section{One-choice tests}

One-choice tests more stringently assess avoidance than two-choice tests. These tests were limited to those repellents to which mice demonstrated a differential response during the two-choice tests. Thus, the response of house mice was assessed with CAP, THI and $\mathrm{C}+\mathrm{T}$, whereas the response of deer mice was assessed only with $\mathrm{C}+\mathrm{T}$.

\subsection{Subjects}

New subjects, experimentally naive house mice (36) and deer mice (12), were adapted to the food deprivation schedule. The procedures were similar, except the divider was removed from the goal box and only one food dish was presented between 0900 and 1500 hours.

\subsection{Repellents}

Repellent formulations and controls used in the onechoice tests were identical to those employed in the two-choice tests.

\subsection{Procedure}

A 4-day pretreatment period followed the 4-day adaptation period. Procedures were the same as during the adaptation period except untreated seeds were presented from 0900 to 1200 hours. After $3 \mathrm{~h}$, the seeds were removed and the animals were given access to rodent chow from 1200 to 1500 hours. Damage was assessed as described for two-choice tests. Procedures for a 4-day treatment period were identical to the pretreatment period except the seeds presented to animals were treated with their respective repellents.

\subsection{Statistical comparison}

Several subjects did not damage seeds during the pretreatment period and were subsequently not included in the statistical analysis. Therefore, the number of mice used in the analysis to assess house mouse responses to $\mathrm{CAP}, \mathrm{THI}$ and $\mathrm{C}+\mathrm{T}$ in one-choice tests were 7,7 and 6 , respectively. Nine deer mice were used to assess their response to the $\mathrm{C}+\mathrm{T}$ repellent. Separate two-factor repeated measures ANOVA were used to assess efficacy of the treatments in reducing seed predation for each of the test. The repeated factors were days (4 levels) and periods (pretreatment and treatment).

\subsection{Results}

House mice damaged fewer seeds during the treat-

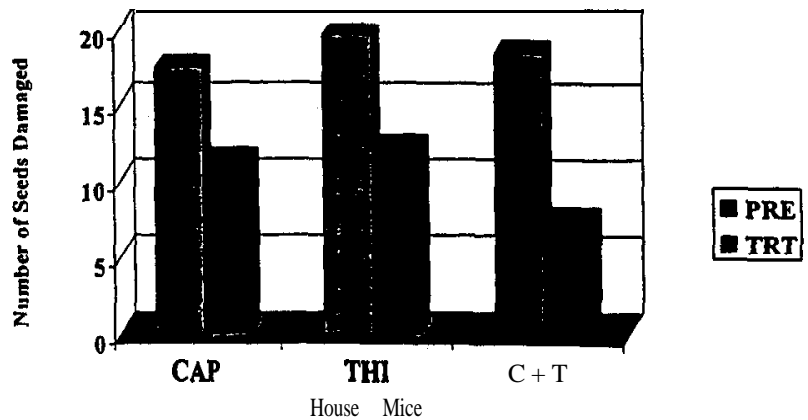

Fig. 3. Mean number of seeds damaged by house mice during a 4 day pretreatment period and during a similar treatment period when seeds were treated with $\mathrm{CAP}$, THI, or $\mathrm{C}+\mathrm{T}$.

ment period than the pretreatment period (Fig. 3), regardless whether the repellent was CAP $(\mathrm{P}=0.0135), \quad$ THI $\quad(P=0.0348), \quad$ or $\quad \mathrm{C}+\mathrm{T}$ $(P=0.0060)$. There were no day effects $(P>0.05)$ or treatment by day interaction $(P>0.35)$ detected in any of the test conducted with house mice. Deer mice also damaged fewer $\mathrm{C}+\mathrm{T}$. seeds $(\boldsymbol{P}=0.0003)$ during the treatment period than they did untreated seeds during the pretreatment period (Fig. 4). There was a day effect $(P=0.0284)$, but not a treatment by day interaction $(P>0.35)$.

\section{Discussion}

Repellents reduced mouse predation of longleaf pine seeds in these experiments. House mouse feeding activity was reduced by all test repellents, whereas seed predation by deer mice was significantly reduced only by the $\mathrm{C}+\mathrm{T}$ mixture. Therefore, the mixture, rather than the single ingredient repellents tested, would be most applicable for future consideration, because seed

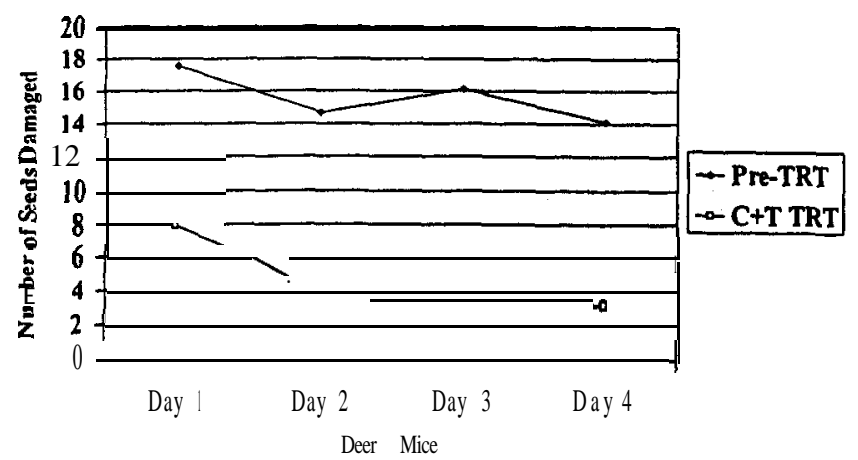

Fig. 4. Mean number of seeds damaged by deer mice on each of 4 days during a pretreatment period and during a similar treatment period when seeds were treated with $\mathrm{C}+\mathrm{T}$. 
predation on reforestation plantations is more likely to be inflicted by species of Peromyscus than by house mice.

These results are consistent with the efficacy demonstrated in field tests conducted by Barnett (1998). Barnett detected minimal $(0.7 \%)$ depredation of seeds treated with $\mathrm{C}+\mathrm{T}$ after 11 days; whereas, more than $50 \%$ of the CAP treated seeds were taken. Our results suggest Peromyscus may account for some of the differences detected in the predation rates between seeds treated with the two repellents. Another contributing factor would be depredation by birds. Birds tolerate high concentrations of capsaicin (Mason et al., 199 1); therefore, the capsicum-based repellent would not be expected to deter bird feeding activity.

Although these experiments suggest the $\mathrm{C}+\mathrm{T}$ mixture may enhance survival of longleaf pine seeds in southern forests, specific site factors will influence the extent of protection and these factors need to be considered prior to implementing a planting program (Nolte, 1998b). Wildlife responses to repellents vary among individuals, as well as among species (Nolte and Mason, 1998). Obviously, responses to repellents that require conditioning will reflect each animal's prior experience. Less obvious, however, are response differences that occur because some species are more responsive to certain stimuli than other species. The response differences of house and deer mice in the reported experiments probably' reflected a sensitivity difference between these species to the test stimuli.

A repellent's efficacy also depends on the desirability of the protected item (e.g., seed) as a food source. Alternative forage will more likely be selected if the protected item is not a valued food source. For example, western red cedar (Nolte, 1998a) is more difficult to protect than foxglove (Nolte et al., 1994a). Thus, an effective program to reduce wildlife damage using repellents also depends on the availability of alternative forage. An abundance of alternative forage permits animals to readily direct their destructive behavior toward other plants. For example, deer mice predation on conifer seeds was reduced if the seeds were distributed along with an abundance of sunflower seeds and oats (Sullivan, 1978). An animal's foraging choices also may reflect the size of the protected area relative to its territorial boundaries. Species with vague or extensive territories, such as birds, can more easily locate alternative forages than can species (e.g., mice) with small and more rigid territorial boundaries.

Foraging pressure on protected plants also depends on the types and densities of wildlife species at a site. Competition among species may cause animals to select foods that they would normally avoid. Likewise, high population densities may limit foraging alternatives, rendering repellents less effective.

\section{Acknowledgements}

Technical support to conduct the experiments was provided by Larry Johnson, and the figures were created by Debbie Byrne. Mice used in these studies were maintained and tested according to approved protocols and animal welfare standards. The use of trade, firm, or corporation names in this publication is for the convenience of the reader, and does not constitute an endorsement by the US Department of Agriculture of any product or service to the exclusion of others that may be suitable.

\section{References}

American Spice Trade Association, 1960. Official Analytical Methods of the American Spice Trade Association. American Spice Trade Association, New York 45 pp.

Association of Official Seed Analysts, 1980. Rules for testing seeds. J. Seed Tech. 3, I-126.

Avery, M.L., Decker, D.G., 1991. Repellency of fungicidal rice seed treatments to red-winged blackbirds. J. Wildl. Manage. 55, 327$334^{\circ}$

Barnett, J.P., 1995. Anipel fails to repel rodents from direct seeded longleaf pine seeds. In: Proceedings of the Eighth Biennial South. Silvicul. Res. Conf., pp. 119-121.

Barnett, J.P., 1998. Oleoresin capsicum has potential as a rodent repellent in direct seeding longleaf pine. In: Proceedings of the Ninth Biennial South, Silvicul Res. Conf.. vol. 9. pp. 326328.

Barnett, J.P., Bergman, P.W.. Ferguson, W.L., 1980. The biologic and economic assessment of endrin. USDA Cooperative Impact Assessment Report. USDA Technical Bulletin 1623. Washington, DC. $47 \mathrm{pp}$.

Campbell, T.E., 1981a. Growth and development of loblolly and slash pines direct-seeded or planted on a cut-over site. South. J. Appl. For. 5, 115-118.

Campbell, T.E.. 1981 b. Spot seeding is effective and inexpensive for reforesting small acreage. Proc. Biennial South. Silvicul. Res. Conf. 1, 50-53.

Campbell, T.E., 198Ic. Effects of endrin in repellent seed coverings on caged rodents. Research Paper SO-174. USDA, Forest Service, New Orleans, LA, Southern Experiment Station. 4 pp.

Campbell, D.L., Bullard, R.W., 1972. A preference-testing system for evaluating repellents for black-tailed deer. Proc. Vert. Pest Conf. 5, 56-63.

Campbell, D.L., Bullard, R.W.. 1994. Chile Institute Newsletter 4, 6.

Clark, L., 1998. Review of bird repellents. Proc. Vertebr. Pest Conf. 18. 330-337.

Derr. H.J., Mann, W.F., 1971. Direct seeding pines in the South. In: Agricultural Handbook 391. USDA, Washington DC $68 \mathrm{pp}$.

Dhindsa, M.S., Sandhu, P.S., Saini. H.K., Toor, H.S.. 1991. House crow damage to sprouting sunflower. Trop. Pest Manage. 37, 179-181.

Green, B.R., Mason, J.R.. Kare, M.R., 1990. Chemical Senses, vol. 2, Irritation. Marcel Dekker, New York.

Hoffman, P.G., Lego, M.C., 1983. Separation and quantization of red pepper major heat principles by reverse-phase high-pressure liquid chromatography. J. Agric. Food Chem. 31, 1326-1330.

Mason, J.R., Adams, M.R., Clark, L.. 1989. Anthranilate repellency to starlings: chemical correlates and sensory perception. J. Wildl. Manage. 53, 55-64.

Mason, J.R., Bean. N.J., Shah, P.S., Clark, L.. 1991. Taxon-specific 
differences in responsiveness to capsaicin and several analogues: correlates between chemical structure and behavioral aversiveness. J. Chem. Ecol.17, 2539-2550.

Nolte, D.L., 1998a. Efficacy of selected repellents to deter deer browsing on conifer seedlings. Intemat. Biodet. Biodeg. 42, 101107.

Nolte, D.L., 1998b. Wildlife considerations when planning plant projects. In: Rose, R., Hasse, D.L. (Eds.), Native Plants: Propagation and Planting. Oregon State University, Corvallis, Oregon, pp. 118-123.

Nolte, D.L., Kimball, B.A., Kelly, K.L., Zhang, Z., Campbell. D.L., 1994a. Herbivore (Aplodontia rufa) avoidance of a simple digitalis extract. J. Agric. Food Chem. 43, 830-832.

Nolte, D.L., Mason, J.R., 1998. Bioassays for mammals and birds.
In: Millar, J., Haynes, K. (Eds.), Methods in Chemical Ecology. Chapman and Hall, London, pp. 326-395.

Nolte, D.L., Mason, J.R., Epple, G., Aronov, E., Campbell, D.L., 1994b. Why are predator urines aversive to prey? J. Chem. Ecol. 20, 1502-1516.

Rozin, P., Ebert, L., Schull, J., 1982. Some like it hot: a temporal analysis of hedonic responses to chili pepper. Appetite 3, 13-22.

Schafer, E.W., Bowles, W.A., Hurlbut, J., 1983. The acute oral toxicity, repellency, and hazard potential of 988 chemicals to one or more species of wild and domestic birds. Arch. Environm. Contam. Toxicol. 12, 355-382.

Sullivan, T.P., 1978. Biological control of conifer seed damage by the deer mouse (Peromyscus maniculatus). Proc. Vertebr. Pest Conf. 8, 237-250. 